WOMEN AND EVIL 
This page intentionally left blank 


\title{
WOMEN AND EVIL
}

\author{
Nel Noddings
}

University of California Press

Berkeley - Los Angeles - London 
This book is a print-on-demand volume. It is manufactured using toner in place of ink. Type and images may be less sharp than the same material seen in traditionally printed University of California Press editions.

University of California Press

Berkeley and Los Angeles, California

University of California Press, Led.

London, England

(C) 1989 by

The Regents of the University of California

Library of Congress Cataloging-in-Publication Data

Noddings, Nel.

Women and evil / Nel Noddings.

p. cm.

Bibliography: $p$.

Includes index.

ISBN 0.520-07413-0 (alk. paper)

I. Good and evil. 2. Women. 3. Feminism. I. Title.

$\mathrm{BJ} \mathrm{x}_{401 . \mathrm{N} 63} \mathrm{r}_{989}$

$170^{\prime} .8804 .2-\mathrm{dc} x 9$

88-8000

CIP

Printed in the United States of America

The paper used in this publication meets the minimum requirements of ANSI/NISO Z39.48-1992 (R 1997)

(Permanence of Paper). @) 
To my daughters -

Chris, Laurie, Nancy, Sharon, and Vickywhose love and companionship have meant so much to me, and to my sons-

Howard, Buzz, Bill, Ed, and Timwhose tenderness with children and animals gives me hope for a better world. 
This page intentionally left blank 